\title{
Letter to the editor regarding "Safety of one-stage bilateral total knee arthroplasty -one surgeon sequential vs. two surgeons simultaneous: a randomized controlled study"
}

\author{
Tomonori Shigemura $^{1}$ (D) Yohei Yamamoto $^{1} \cdot$ Yuichi Wada $^{1}$ \\ Received: 15 July 2020 / Accepted: 16 July 2020 / Published online: 20 July 2020 \\ (C) SICOT aisbl 2020
}

We read with great interest an article titled "Safety of onestage bilateral total knee arthroplasty -one surgeon sequential vs. two surgeons simultaneous: a randomized controlled study" by Uzer et al. [1] published in the July 2020 issue of the journal and would like to congratulate the authors for their study. The authors performed a prospective randomized study to detect the differences between two-surgeon bilateral total knee arthroplasty (TKA) and single-surgeon bilateral TKA in terms of complication rate and functional scores in the early post-operative follow-up. The most important finding of the study was that two-surgeon bilateral TKA on the earliest postoperative follow-up had significantly lower major complication rates and operating times than single-surgeon bilateral TKA. Although they have touched a highly pertinent topic in a scientific manner, the study has brought an important issue that we would like to communicate with the authors.

The authors did not show radiological results in their study. Precise component alignment is a crucial prognostic factor in terms of wear and subsequent loosening, which may impact the long-term outcome of TKA [2-4]. Qadir et al. indicated that there were no significant differences in component alignment between one-surgeon sequential bilateral TKA and unilateral TKA [5]. Were there any differences between twosurgeon simultaneous bilateral TKA and single-surgeon sequential bilateral TKA in terms of component alignment? We speculated that two-surgeon bilateral TKA is at a disadvantage in accurate prosthesis implantation because the soft tissue retractors of both sides may interfere with each other that cause an inadequate operative field. In addition, there is a possibility that the surgeon or assistant of the other surgical team may be in the way of the precise component implantation. Please let us know if the authors have any ideas for achieving good component alignment in two-surgeon simultaneous bilateral TKA.

\section{Compliance with ethical standards}

Conflict of interest The authors declare that they have no conflict of interest.

\section{References}

1. Uzer G, Aliyev O, Yıldız F, Güngören N, Elmalı N, Tuncay İ (2020) Safety of one-stage bilateral total knee arthroplasty -one surgeon sequential vs. two surgeons simultaneous: a randomized controlled study. Int Orthop. https://doi.org/10.1007/s00264-020-04704-9

2. Ritter MA, Faris PM, Keating EM, Meding JB (1994) Postoperative alignment of total knee replacement. Its effect on survival. Clin Orthop Relat Res 299:153-156

3. Jeffery RS, Morris RW, Denham RA (1991) Coronal alignment after total knee replacement. J Bone Joint Surg Br 73:709-714

4. Moreland JR (1988) Mechanisms of failure in total knee arthroplasty. Clin Orthop Relat Res 226:49-64

5. Qadir I, Shah B, Waqas M, Ahmad U, Javed S, Aziz A (2019) Component alignment in simultaneous bilateral versus unilateral total knee arthroplasty. Knee Surg Relat Res 31:31-36. https://doi.org/ $10.5792 /$ ksrr. 18.049

Publisher's note Springer Nature remains neutral with regard to jurisdictional claims in published maps and institutional affiliations.

Tomonori Shigemura

tshigepon@yahoo.co.jp

1 Department of Orthopaedic Surgery, Teikyo University Chiba Medical Center, 3426-3 Anesaki, Ichihara, Chiba 299-0111, Japan 